\title{
Bioactivity of Pure Antibacterial Compounds From Endophytic Fungus of Sporothrix sp Against Bacteria Escherichia coli and Staphylococcus aureus
}

\author{
Dewi Yudiana Shinta ${ }^{1}$, Yusmarini ${ }^{2}$, Herix Sonata MS $^{3}$, Hilwan Yuda Teruna ${ }^{4}$ and Saryono ${ }^{5}$ \\ 1'dyshinta@stikesperintis.ac.id, ${ }^{2}$ yusmarini@lecturer.unri.ac.id, ${ }^{3}$ herix_sonata@itp.ac.id, \\ 4hyteruna@lecturer.unri.ac.id, ${ }^{5}$ saryono@lecturer.unri.ac.id \\ ${ }^{1}$ STIKES Perintis Padang, Indonesia \\ ${ }^{2}$ Department of Agriculture, University of Riau, Pekanbaru, Indonesia \\ ${ }^{3}$ ITP Padang Indonesia \\ ${ }^{4,5}$ Department of Chemistry, University of Riau, Pekanbaru, Indonesia
}

\begin{abstract}
Modern drugs that are developing now come from active ingredients isolated from plants that require large amounts of plants. The development of new drugs from endophytic fungi finds problems in the amount of pure compounds produced. Therefore, further research is needed using endophytic fungi as a new antimicrobial producer. This study aims to see the ability or activity of pure compounds produced by endophytic fungi Sporothrix $s p$ from dahlia bulbs (Dahlia variabilis). The activity test of pure compounds produced by Sporothrix sp endophytic fungus against E.coli and Staphylococcus aureus was determined by disc diffusion method. With a dose of 10.30 and $50 \mu \mathrm{g} / \mathrm{disk}$.

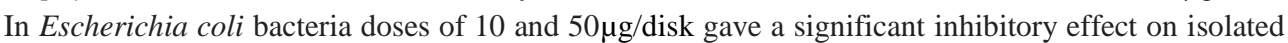
pure compounds compared to the positive control of ciprofloxacin, which was characterized by a statistically significant test ( $\mathrm{p}<0.05$ ). In contrast to Staphylococcus aureus there was no significant difference in dosage of both 10.30 and $50 \mu \mathrm{g} /$ disk doses. Determination of pure compounds was carried out by HPLC and Infra Red Spectrofotometric.
\end{abstract}

Keywords: Dahlia Bulbs (Dahlia variabilis), Endophytic fungus of Sporothrix sp, E.coli, Staphylococcus aureeus.

\section{Introduction}

The continuous use of synthetic antibacterial drugs not only kills the bacteria itself but also accelerates the occurrence of pathogenic resistance. For this reason, alternative safe antibacterial drugs from natural ingredients are needed.

The source of new bioactive ingredients that are widely explored today is endophytic fungus. This is because endophytic fungus can produce secondary metabolites that can be developed into medicinal raw materials. The compounds produced by endophytic fungus often have greater activity than the activity of the host plant compounds (1). Breeding or culture of endophytic fungus can be carried out in very large quantities without requiring large areas of land such as plants. The use of endophytic fungus as a source of natural medicine raw materials will reduce natural damage caused by the exploitation of large amounts of medicinal plants.

The production of antimicrobial compounds from plants in mass quantities requires plants in large quantities, so that a large area is needed and a relatively longer time waiting for the plant growth period. 
These constraints can be overcome by isolating secondary metabolites from microbes. One of them is endophytic microbes that live in plant tissues (2).

Fitriyah, et al. (2014) reported that endophytic fungi of dahlia bulbs that had been isolated were Monilia sp (LBKURCC 40), Fusarium sp (LBKURCC 41), Moniliella sp (LBKURCC 42), and Sporothrix sp (LBKURCC43). Of the four isolates above have antimicrobial bioactivity against Gram positive, Gram negative bacteria and fungi. Fusarium sp (LBKURCC 41) and Sporothrix sp (LBKURCC 43) are endophytic dahlia mushrooms that produce secondary metabolites that have antimicrobial activity against E. coli and Staphylococcus aureus, but the secondary metabolites produced have not been purified and their chemical structure and bioactivity have not been determined microbes that cause infectious diseases have also not been carried out (3).

This study aims to see the ability or activity of pure compounds produced by endophytic fungus Sporothrix sp from Dahlia tuber (Dahlia variabilis). In this study will be found what dose of pure compounds found from secondary metabolites of Sporothrix sp fungi that can inhibit the growth of E.coli and Staphylococcus aureus bacteria.

\section{Methods}

The tools used in this study are Autoclaf 1925x (Wiconsin Alumium Foundry Co.Inc.Monitowoc), High Speed Micro Centrifuge CT 15RE Models, vortex mixer H-VM-300, SUB28 Grant Water Baths, Memmert incubators, rotary shakers (Daihan Labtech Co.LTD), spectrophotometer IR Shimadzu Prestige 2100, HPLC, oven, petri dish, needle ose, bunsen, gas stove, glass stirrer, tweezers, filter paper, incubator, aluminum foil, microscope, cover glass, object glass, measuring cup , test tube, volume pipette, erlenmeyer, calipers, media bottles, shaker incubator, centrifugation, analytic scales and razor blades.

The ingredients used are Potato Dextrose Agar (PDA) Cat 1.10130.0500 no., Sabouraud Dextrose Broth (SDB) Paint No. 1.08339.0500, Sabouraud Dextrose Agar (SDA), Nutrient Agar (NA) media No paint 1.05450,0500, Nutrient Broth (NB) media no paint 1.05443.0500. (all media produced by Merck KGaA Germany), sodium chloride ( $\mathrm{NaCl}$ ), media Huang et al (2007), Potassium Dihydrogen Pospat (KH2PO4), Magnesium sulfate hepta hydrate $(\mathrm{MgSO} 4.7 \mathrm{H} 2 \mathrm{O})$, and iron sulfate hepta hydrate (FeSO4.7H2O ) Milipore syringe filter is $0.2 \mu \mathrm{m}$ (Puradisc TM 13mm paint no 6786-1302), 6mm disc paper (macherey-nagel MN827ATD). Endophytic fungi Sporothrix sp LBKURCC 43 which has been isolated from dahlia bulbs (Dahlia variabilis) in previous studies ( Lorenita, 2011) The microorganisms used in the antimicrobial test were Stapylococcus aureus, Escherichia coli, which were obtained from the collection of the Faculty of Medicine, Andalas University, Padang.

\subsection{Research Procedure}

Isolate Production

Fermentation was carried out at optimum conditions, namely temperature $37^{\circ} \mathrm{C}, \mathrm{pH} 4$, aeration $50 \mathrm{vvm}$, agitation $150 \mathrm{ppm}$ with variation of Huang et al media with ammonium sulfat and $\mathrm{Na} \mathrm{CMC}+$ sucrose with a volume of 6 liters. The composition of the media can be seen in table 1 below.

Table 1. Composition of media variations Huang et al (2007)

\begin{tabular}{cc}
\hline Composition & Volume \\
\hline Na CMC + Sukrosa & $42+126 \mathrm{~g}$ \\
\hline $\mathrm{NaNO}_{3}$ & $18 \mathrm{~g}$ \\
\hline $\mathrm{KH}_{2} \mathrm{PO}_{4}$ & $9 \mathrm{~g}$ \\
\hline Amonium sulfat & $9 \mathrm{~g}$ \\
\hline $\mathrm{KCl}$ & $3 \mathrm{~g}$ \\
\hline $\mathrm{MgSO}_{4} .7 \mathrm{H}_{2} \mathrm{O}$ & $3 \mathrm{~g}$ \\
\hline $\mathrm{FeSO}_{4} .7 \mathrm{H}_{2} \mathrm{O}$ & $0,06 \mathrm{~g}$ \\
\hline Aquadest & $6 \mathrm{~L}$ \\
\hline
\end{tabular}




\section{Isolate Extraction}

Isolates were extracted by flash chromatography method. Further separation of a fraction so as to obtain pure isolates can be carried out by flash chromatography. The size of the flash chromatography column used is $2.5 \mathrm{~cm}$ in diameter. The stationary phase used silica gel $230-400 \mathrm{~nm}$ with a ratio of many silica gel columns with samples is 1: 50-60. Silica gel in the column is made by dry by means of silica put in a column which has contained a little solvent to be used for elution and then shaken so that the solvent and silica mix. Then the column is pressed with an air pump so that silica solidifies. Then a number of samples that have been dissolved in a little solvent to be used are placed over the silica column. Samples of 2.7 grams impregnated with 3 grams of silica were further separated using flash chromatography.

\section{Separation of Sporothrix sp ethyl acetate extract with VLC (Liquid Vacuum Chromatography)}

Liquid vacuum chromatography $(10 \mathrm{~cm}$ in diameter and $20 \mathrm{~cm}$ in height) is filled with silica gel 60 GF254 until it reaches a height of approximately $10 \mathrm{~cm}$. Column filling is carried out under vacuum, so that maximum packing density is obtained. $2.7 \mathrm{~g}$ of the sample was pre-adsorbed and then inserted into the column. Then fractionated with gradient using n-hexane-ethyl acetate ratio of 70:30 a 10\% polarity increase until the ratio of methanol-ethyl acetate (50:50) increased by $10 \%$ polarity. The results of the separation are stored in Erlenmeyer which has been numbered and concentrated with rotary evaporator, then the TLC test is conducted to determine the number of components of each fraction. Fractions that have the same stain pattern are combined. The F3-F5 fraction was obtained in the form of crystals and then washed with ethyl acetate and then revitalized with dichloromethane, can be seen in table 2 below.

Table 2. Fractions that have a stain pattern on KLT

\begin{tabular}{cccc}
\hline $\begin{array}{c}\text { No } \\
\text { Fraksi }\end{array}$ & Eluen & Berat $(g)$ & $\begin{array}{c}\text { Jumlah } \\
\text { Noda }\end{array}$ \\
\hline F1 & $\mathrm{H}: \mathrm{E}=7: 3$ & 0,3174 & \\
\hline $\mathrm{F} 2$ & $\mathrm{H}: \mathrm{E}=6: 4$ & 0,1311 & \\
\hline F3 & $\mathrm{H}: \mathrm{E}=5: 5$ & 0,3024 & \\
\hline F4 & $\mathrm{E}=100 \%$ & 0,6880 \\
\hline F5 & $\mathrm{E}: \mathrm{M}=9: 1$ & $0,0,71$ \\
\hline F6 & $\mathrm{E}: \mathrm{M}=8: 2$ & 0,1319 \\
\hline F7 & $\mathrm{E}: \mathrm{M}=7: 3$ & 0,511 \\
\hline F8 & $\mathrm{E}: \mathrm{M}=6: 4$ & 0,0637 \\
\hline F9 & $\mathrm{E}: \mathrm{M}=5: 5$ & 0,049 \\
\hline
\end{tabular}

\section{Separation of Sporothrix sp ethyl acetate extract with Flash chromatography}

Columns can be made by making silica gel slurry (230-400) by dissolving it with $n$-hexane solvent and stirring evenly. Then poured into the column slowly. Silica gel in the column is made solid and the surface should not dry. Column elution was carried out with various eluents having increased polarity, ranging from $100 \% \mathrm{n}$-hexane, ratio of $\mathrm{n}$-hexane to ethyl acetate to $100 \%$ ethyl acetate. A total of 1.5 grams of sample are first absorbed before they are inserted into the column, then eluted with a solvent to form ribbons. Fractionation results that come out are collected in a numbered vial.

The fractions resulting from the separation by column chromatography indicating the presence of crystals were tested by KLT to determine the same Rf (Retardation factor) prices so that they could be combined. The crystals formed were recrystallized then the crystallized crystals were carried out by TLC test and HPLC test.

This HPLC analysis was carried out using the elution gradient method. The sample was dissolved with methanol (HPLC grade) ( $1 \mathrm{mg}$ in $1 \mathrm{~mL}$ methanol). The solution is then filtered with a $0.45 \mu \mathrm{L}$ 
whatman filter. A filtrate of $20 \mu \mathrm{L}$ was injected into the column, then the sample was analyzed for 20 minutes using the appropriate method. The column used in HPLC is Shim-pack VP-ODS with a length and diameter of $150 \times 4.6 \mathrm{~mm}$. Crystals of pure compounds were characterized using IR spectroscopy.

Antimicrobial activity test of pure compounds (Kirby Bauer method)

a. Making media in order

The media used for antibacterial tests are NA (Nutrient agar) and antifungal test media, namely PDA (potato dextrose agar). 20 grams of NA were dissolved in $1000 \mathrm{ml}$ of aquadest and put into a test tube, $15 \mathrm{ml}$ each. The media was closed and sterilized at $121^{\circ} \mathrm{C}$ and 15 psi for 15 minutes (4). A PDA of 39 grams was dissolved in $1000 \mathrm{ml}$ of aquadest then the media was put into a test tube, 15 $\mathrm{ml}$ each. The media was closed and sterilized at $121^{\circ} \mathrm{C}$ and 15 psi for 15 minutes (4).

b. Microbial Rejuvenation

Microbial Rejuvenation aims to rejuvenate bacteria (Staphylococcus aureus and Escherichia coli) from being tilted into NB solution. NB media that has been made is put into a test tube and sterilized. Bacteria from tilting are taken using a sterile ose needle, then inoculated into the NB media. The tube is covered with cotton and then incubated in an incubator at $37^{\circ} \mathrm{C}$ for 24 hours.

c. Antibacterial test

The media was heated to melt and cooled at $50{ }^{\circ} \mathrm{C}$ in a waterbath, then added $1 \mathrm{ml}$ of E.coli and S.Aureus culture (OD600nm-0.1) (5) into a tube, then homogenized and poured into a petri dish. After the media compacted, the disc paper that has been dripped with the test sample (concentration of $500 \mu \mathrm{g} / \mathrm{ml}, 300 \mu \mathrm{g} / \mathrm{ml}$ and $100 \mu \mathrm{g} / \mathrm{ml}$ ) is placed on the agar medium. The positive control used is ciproflocaxin with a concentration of $300 \mu \mathrm{g} / \mathrm{ml}$ and a negative control is DMSO which is used to dissolve the sample. Petri dishes were incubated in an incubator at $37^{\circ} \mathrm{C}$. The diameter of the inhibitory area of bacterial growth was measured after 24 hours incubation. All treatments were aseptic and repeated twice. (4).

\section{Results}

The thick extract produced from the evaporation process is 2.7 grams of 6 liters of fermentation, with a dark brown color and a distinctive smell of ammonia. The dry extract obtained after the evaporation process is 0.3024 grams.

The purification results of 6 liters of samples from isolation of endophytic fungus Sporothrix $s p$ (LBKURCC 43) mushroom extract were carried out by thin layer chromatography (TLC) method with various variations of eluent composition showing a single stain and repeated on each composition.

A total of $0.3024 \mathrm{~g}$ samples were pre-adsorbed and then inserted into the column. Then fractionated with gradient using solvent hexane-ethyl acetate ratio 70:30 increase in polarity of $10 \%$ to the ratio of methanol-ethyl acetate (50:50) increase in polarity of $10 \%$. The results of the separation are stored in erlemeyer which has been numbered and concentrated with rotary evapaporator, then the TLC test is conducted to determine the number of components of each fraction. Fractions that have the same stain pattern are combined. The F3-F5 fraction was obtained in the form of pure crystals and then washed with ethyl acetate and then revitalized with dichloromethane. F3 compounds were carried out purity tests with TLC and HPLC which can be seen in table 3 below.

Table 3. TLC test results from each fraction.

\begin{tabular}{cccc}
\hline $\begin{array}{c}\text { No } \\
\text { Fraction }\end{array}$ & Eluen & Weight $(\mathbf{g})$ & spot \\
F1 & $\mathrm{H}: \mathrm{E}=7: 3$ & 0,3174 & 6 \\
F2 & $\mathrm{H}: \mathrm{E}=6: 4$ & 0,1311 & 5 \\
F3 & $\mathrm{H}: \mathrm{E}=5: 5$ & 0,3024 & 4 \\
F4 & $\mathrm{E}=100 \%$ & 0,6880 & 4 \\
\hline
\end{tabular}




\begin{tabular}{llcl}
\hline F5 & E:M $=9: 1$ & $0,0,71$ & 5 \\
F6 & E:M $=8: 2$ & 0,1319 & 4 \\
F7 & E:M $=7: 3$ & 0,511 & 5 \\
F8 & E:M $=6: 4$ & 0,0637 & 5 \\
F9 & E:M $=5: 5$ & 0,049 & 6 \\
\hline
\end{tabular}

Measurements using the IR (infra red) spectrum indicate a sharp and distinct absorption at several wavelengths. The results of the analysis of the infrared spectrum of F3 compound from the isolation of endophytic fungus extract of Sporothrix $s p$ are shown in Figure 1.

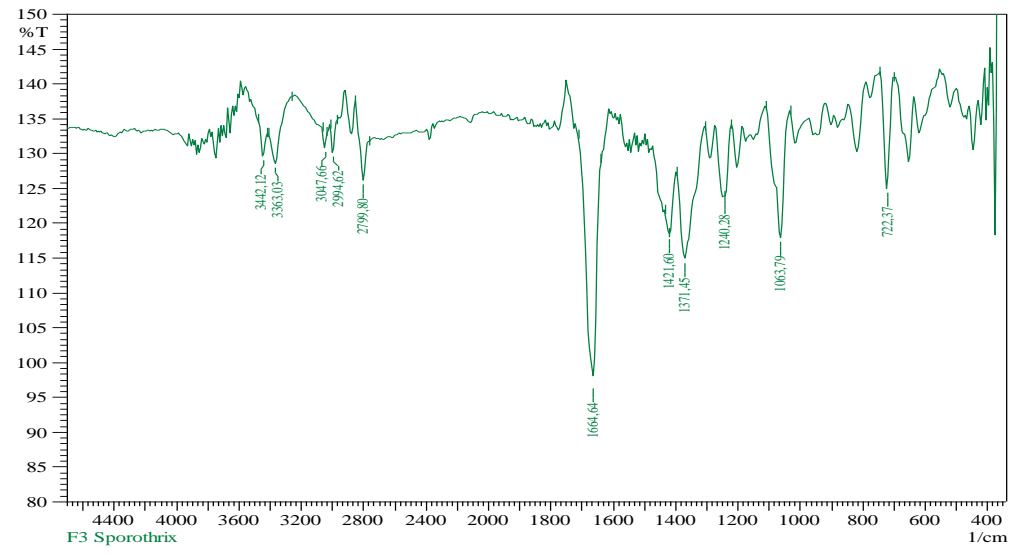

Figure 1. Infra red spectrum of compound F3

The infrared spectrum shows the presence of bands for uptake for $\mathrm{NH}$ amine groups at wavelengths from 3300 to $3000 \mathrm{~cm}-1$, NH flexural stretches in the area of 1650-1580 cm-1, for amines can also be seen in the area of 910-665 cm-1 .. The C-N stretch vibration of the aliphatic amine is observed as a medium or weak band in the region of $1250-1020 \mathrm{~cm} 1$. In aromatic amines, the band is usually strong and in the region of $1335-1250 \mathrm{~cm}-1$. N-H stretches from 3400 to $3250 \mathrm{~cm}-1,1^{\circ}$ amine: two bands from 3400-3300 and 3330-3250 cm-1, $2^{\circ}$ amines: one band from 3350-3310 cm-1, $3^{\circ}$ amine: no band in this region $\mathrm{N}-\mathrm{H}$ is bent (only primary amines) from 1650-1580 cm-1, Stretch $\mathrm{C}-\mathrm{N}$ (aromatic amine) from 1335-1250 cm-1, C-N stretch (aliphatic amines) from 1250-1020 cm- 1, N-H wag (primary and secondary only) from 910-665 cm-1.

HPLC Spectroscopy Measurement using HPLC (High Performance Liquid Cromatography). The results can be seen in Figure 2. For the test the purity of the compound can be seen in the chromatogram that one peak appears, this indicates that the compound is pure. 
\&

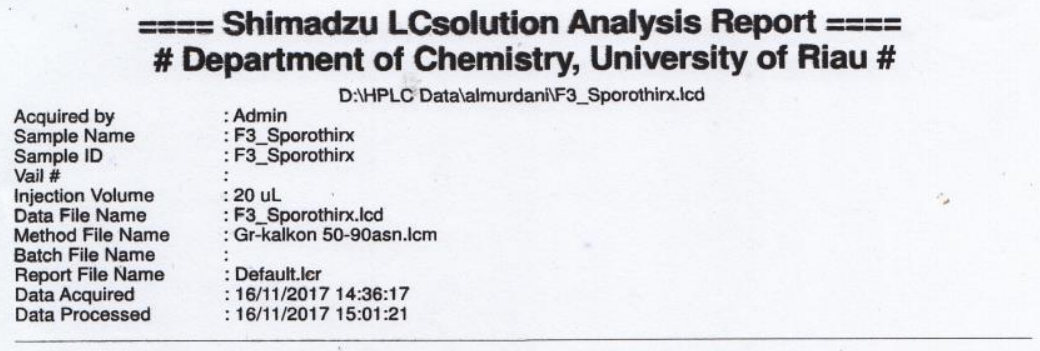

<Chromatogram>

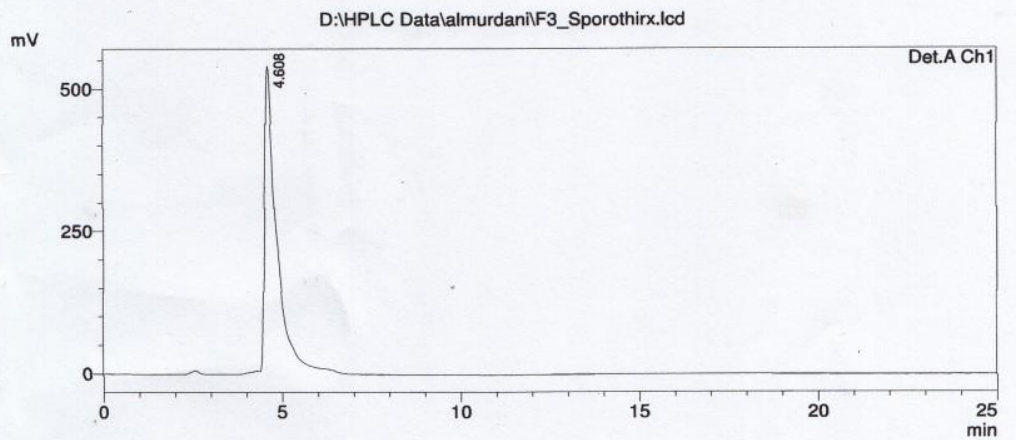

$\mathrm{mV}$

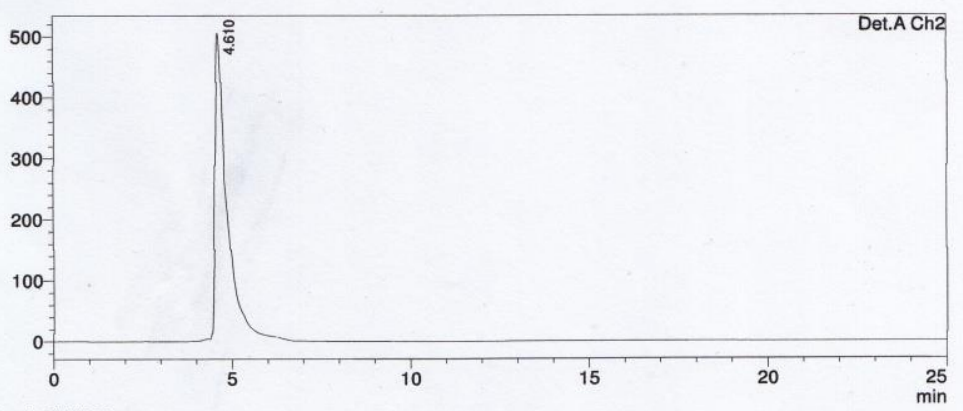

1 Det.A Ch1/229nm

D:IHPLC DatalalmurdaniF3 Sporothirx.lco

Figure 2. Test results with HPLC.

Testing of isolated compounds to test Escherichia coli and Staphylococcus aureus bacteria. 
Bioactivity test for compound F3 The isolation results on these bacteria are stated in Table 4.

\begin{tabular}{|c|c|c|c|c|}
\hline \multicolumn{5}{|c|}{ Average Diameter (mm) } \\
\hline Pure compound & & Dos & used & \\
\hline F3 Isolation Result & $10 \mu \mathrm{g} /$ disk & $30 \mu \mathrm{g} / \mathrm{disk}$ & $50 \mu \mathrm{g} / \mathrm{disk}$ & $\mathrm{K}+$ \\
\hline Escherichia coli & 29,10 & 32,60 & 38,40 & 47,60 \\
\hline Staphylococcus aureus & 29,40 & 29,80 & 31,40 & 45,10 \\
\hline
\end{tabular}

The inhibition zone formed is shown in Figure 3 below.

1. Against Escherichia coli bacteria

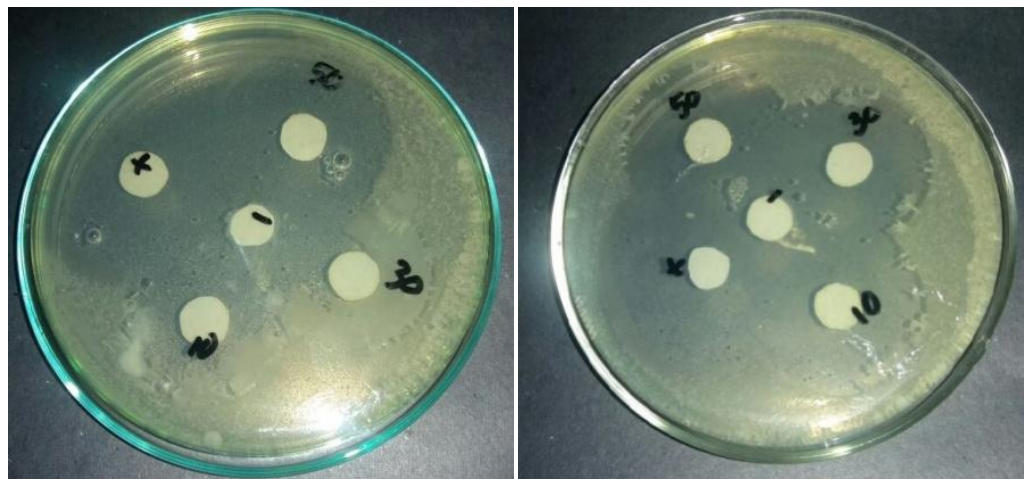

2. Against Bakteri Staphylococcus aureus

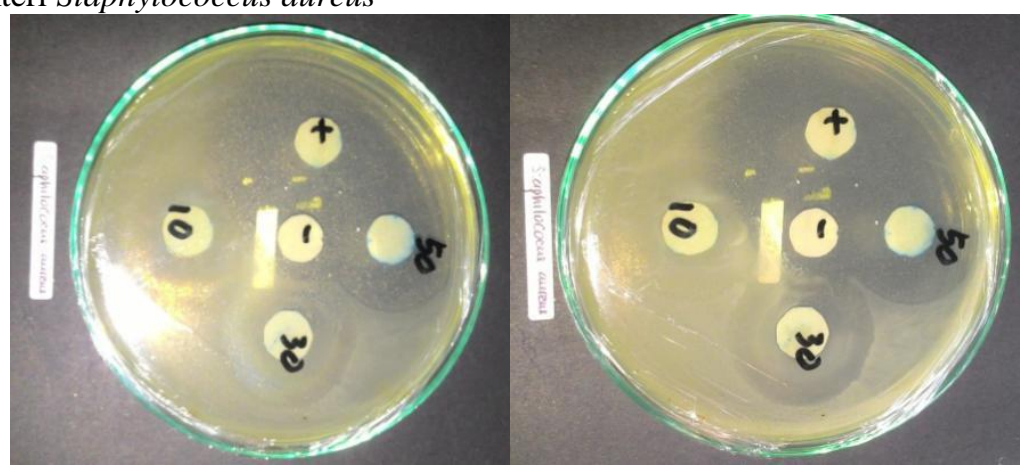

Figure 3. Inhibition zone formed in media variation Huang et al (2007) with doses of 10, 30 and $50 \mu \mathrm{g}$ / disk.

The test results of inhibition of pure compound $\mathrm{F} 3$ above shows that the pure compound provides a large inhibition at a dose of $50 \mu \mathrm{g} /$ disk which is seen in the inhibitory power of $38.40 \mathrm{~mm}$ Escherichia coli bacteria. In Staphylococcus aureus bacteria also provide inhibition of $31.40 \mathrm{~mm}$, while in positive control ciproploxacin is $47.60 \mathrm{~mm}$.

The selection of ciprofloxacin as a positive control because ciprofloxacin is a class of flouoquinolone drugs which serves to inhibit bacterial DNA synthesis so that it inhibits microbial resistance and is a broad-spectrum antimicrobial and microbial resistance does not develop rapidly. (6). 
In Escherichia coli bacteria doses of 10 and $50 \mu \mathrm{g} /$ disk provide significant inhibitory power on isolated F3 compounds. In contrast to Staphylococcus aureus there were no significant differences in dosages of 10.30 and $50 \mu \mathrm{g} / \mathrm{disk}$. From the shape of the chromatogram found from the results of IR and HPLC spectrophotometers, the presence of amine groups which generally can function as antibacterial and antifungal.

From the results of HPLC and IR Spectrophotometer analysis, pure F3 compounds contain terpenoids which function to kill bacteria by denaturing cell proteins where cell protein bonds with terpenoids which cause the cell protein to break down. The hydrogen bond formed will interfere with the permeability of cell walls and cytoplasmic membranes, both of which are composed of proteins. Permeability of disrupted cell walls and cytoplasmic membranes will cause an imbalance of macromolecules and io in the cell resulting in cell lysis. terpenoids are also able to bind with fat and carbohydrates which cause permeability of the bacterial cell wall to be disrupted (29).

\section{Conclusion}

Antibacterial test results of pure compounds against Escherichia coli gave significant inhibitory at doses of 10 and $50 \mu \mathrm{g} /$ disk and there was no significant difference between Stapylococcus aureus for all three doses.

\section{ACKNOWLEDGMENTS.}

This research is funded by Dikti from doctoral dissertation research Scheme 2018 on behalf of the Dewi Yudiana Shinta, M.Si, Apt.

\section{REFERENCES}

1) crobial Endophytes and Their Natural Products. Microbiology and Molecular Biology Reviws 67: 491-502.

2) Saryono,et al, 2015, Antimicrobial activity and molecular characterization of endophytic fungi strain isolated from Dahlia (Dahlia variabilis), Journal of Chemical and Pharmaceutical Research, vol 7((S): 201-208, ISSN 0975-7384.

3) Elita, A., Saryono, S.,dan Christine, J., 2013, Penentuan Waktu Optimum Produksi Antimikroba dan Uji Fitokimia Senyawa uji fermentasi bakteri endofit pseudomonas Sp. dari umbi tanaman Dahlia (dahlia variabilis), Journal Ind. Che. Acta Vol 3 (2) 56 - 62.

4) Fitriyah, D., Saryono. S, dan C. Jose., 2013, Skrining aktivitas antimikroba dan uji fitokimia dari kapang endofitik tanaman dahlia (dahlia variabilis), Journal Ind. Che. Acta Vol 3 (2) 50-55

5) Gan, V.H.S dan Setiabudy, R. 2000. Farmakologi Dan Terapi. Edisi 3. Jakarta: Bagian Farmakologi Fakultas Kedokteran Universitas Indonesia.

6) Guo B, Dai J, Ng S, Huang Y, Leong C, Ong W, Carte BK.. 2002. Cytonic acid A dan $B$, novel tridepside inhibitor of $h C M V$ protease from the endophytic fungus Cytonaena sp. $\mathrm{J}$ Nat Prod 63:602-604.

7) Halim, Jasril, dan Saryono, 2014, Optimalisasi Produksi Senyawa Metabolit Sekunder dari Pseudomonas sp Endofit Tanaman Dahlia (Dahlia variabilis), Ind.Che.Acta vol 5(1) 8-14.

8) Haniah.M, 2008, Isolasi jamur Endofit dari Daun Sirih (Piper betle L) Sebagai Antimikroba Terhadap Eschericia coli, Staphylococcus aureus dan Candida albicans,UIN Malang.

9) Haryani,Y., Siti Muthmainah dan Saryono Sikumbang, 2013, Uji Parameter Non Spesifik dan Aktivitas Antibakteri Ekstrak Metanol dari Umbi Tanaman Dahlia (Dahlia variabilis), Jurnal Penelitian Farmasi Indonesia 1(2), Maret 2013: 43-46.

10) Huang, W.Y., Cai, Y.Z., Hyde, K.D., Corke, H., \& Sun, M. 2007. Endophytic fungi from Nerium oleander L (Apocynaceae) main constituents and antioxidant activity. World Journal of Microbiology and Biotechnology 23(9)1253-1263. 
11) Lorenita,M.,et al, 2013, Screening of Endophytic Fungi from Tubers of Dahlia variabilis, Journal of Agricultur Technology, vol 9(3): 565-570.

12) $\mathrm{Lu} \mathrm{H}$, Zou WX, Meng JC, Hu J, Tan RX. 2000. New bioactive metabolites produced by Colletotrium sp., an endophytic fungus in Artemisia annua. Plant Sci151:76-73.

13) Purwantini, I, Ratna H, A. Dan Eka P. P, 2010, Isolasi Fungi Endofit Penghasil Antifungi dari Eupatorium riparium Reg. Dan Identifikasi Senyawa Aktifnya Menggunakan Bioautografi, Prosiding Seminar nasional, Eight performance Pharmacist, 27 Desember 2010, UGM Yogyakarta, hal 149.

14) Prihatiningtias,W. 2007. Prospek Mikrob Endofit Sebagai Sumber Senyawa Bioaktif, Majalah Obat Tradisional 12 (42).

15) Pratiwi,S.T, 2008. Mikrobiologi Farmasi,Jakarta, Erlangga.

16) Qadri, M, et,al, 2013, Identification and bioactive potential of endophytic fungi isolated from selected plants of the Western Himalayas, Qadriet al. Springer Plus 2013,2:8, 2-14.

17) Radji, M. 2005. Peranan Bioteknologi dan Mikroba Endofit dalam Pengembangan Obat Herbal. Laboratorium Mikrobiologi dan Bioteknologi. Vol. II. Departemen Farmasi, FMIPA-UI, Majalah Ilmu Kefarmasian, ,No.3,Desember.

18) Rante, H, Burhanuddin Taebe dan Soendaria Intan, 2013, Isolasi Fungi Endofit Penghasil Senyawa Antimikroba Dari Daun Cabai Katokkon (Capsicum annuum L var. chinensis) dan profil KLT BIOAUTOGRAFI, Majalah Farmasi dan Farmakologi, Vol. 17, No.2 - Juli 2013, hlm. 39 - 46.

19) Ryan.J.K, 2004, Medical Microbiology, An Introduction to Infectious Diseases, Prentice Hall International Inc.

20) Ristiati, N. P. 2000. Pengantar Mikrobiologi Umum. Proyek Pengembangan sekolah menengah IBRD Loan Direktorat Jendral Pendidikan Tinggi: Departemen Pendidikan Nasional.

21) Saryono S.dkk.2013, Penentuan Waktu Optmum Produksi Antimikroba dan Uji Fitokimia Ekstrak Kasar Fermentasi Bakteri Endofit Pseudomonas sp dari Umbi Tanaman Dahlia (Dahlia variabilis),Jurnal.Ind,Che.Acta Vol.3 (2) 2013.

22) Saryono, Hindersah,2009, Tanaman Dahlia Potensi Bahan Alam Sumber Karbohidrat dan Senyawa Bioaktif, Unri Press, Pekanbaru.

23) Sadrati, N, et al, 2013, Screening Of Antimicrobial And Antioxidant Secondary Metabolites From Endophytic Fungi Isolated From Wheat (Triticum Durum), Journal Of Plant Protection Research Vol. 53, No. 2: 128-136.

24) Selim, KA, El-Beih AA, Abd El-Rahman TM and El-Diwany AI, 2012, Biology of Endophytic Fungi, Current Research in Environmental \& Applied Mycology, 31-81.

25) Simarmata, Rumilla. 2007. Isolasi Mikroba Endofitik dari Tanaman Obat Sambung Nyawa Gynura Procumbens) dan Analisis Potensinya sebagai Antimikroba. Jurnal penelitian Hayati 13 : 85-90.

26) Sinaga,E. dkk,2009, Daya antibakteri Jamur Endofit yang Diisolasi Dari Dan Dan Rimpang Lengkuas (Alpinia galanga sw), Jurnal Farmasi Indonesia vol 4.no4 Juli 2009 :161-170.

27) Sinaga,E,dkk, 2009, Isolasi dan Uji Aktivitas Antibakteri Jamur Endofit DariDaun Dan Rimpang Zingiber ottensii Val, Jurnal Farmasi Indonesia,vol 4.(4) : 171-176.

28) Simanjuntak P, Parwati T, Bustanussalam, Prana TK, Wibowo S, Shibuya H. 2002. Isolasi dan kultivasi mikroba endofit penghasil senyawa alkaloid kinkona dari Chinchona spp. J Mikrobiol 7:27-30.

29) Shinta, D.Y, et al, 2015, The Media Variance of Production for Anti Microbe Homogeny from the Endofite Mushroom of Dahlia Plant Seed (Dahlia variabilis), Journal of Chemical and Pharmaceutical Research, 7(9S): 239-245.

30) Bonjura,S.,dkk, 2015, Uji anti bakteri ekstrak daun Leilem (Clerodendum minahassae.L) Terhadap Bakteri Streptococcus mutan, Jurnal Ilmiah Farmasi Unsrat Vol4 no 4, ISSN 2302-2493. 